\title{
Trace-metal content of the Pueblo Viejo precious-metal deposits and their relation to other high-sulfidation epithermal systems
}

Received: 30 November 2002/ Accepted: 12 December 2002/Published online: 12 April 2003

(C) Springer-Verlag 2003

\begin{abstract}
We provide here information on the distribution of copper, zinc, lead, gold, silver, barium, arsenic, antimony, mercury, selenium and tellurium in the Moore and Monte Negro high-sulfidation epithermal deposits in the Pueblo Viejo district, Dominican Republic. Moore and Monte Negro are funnel-shaped zones of advanced argillic alteration and precious-metal mineralization which extend to depths of about $350 \mathrm{~m}$ below the present surface. The uppermost part of the Moore deposit has been removed by erosion, whereas the Monte Negro deposit is covered by rocks containing low, but still anomalous gold grades. At Moore, concentrations of all elements except copper increase upward through the deposit. At Monte Negro, all elements except barium and zinc show a similar upward increase in concentration to a point near the top of the deposit from which they decrease upward. This difference reflects the fact that the top of the Moore deposit has been removed by erosion. Because the deposits are funnelshaped and average metal concentrations increase by almost an order of magnitude upward, most of the metals are concentrated in the upper parts of the deposits. The upward increase in concentration of most metals is gradual and similar in magnitude to the prograde temperature dependence in solubilities of many metal complexes, suggesting that the metals were deposited by cooling. By contrast, concentrations of mercury and, to a lesser extent, tellurium increase more
\end{abstract}

Editorial handling: N. White

S. E. Kesler $(\bowtie)$

Department of Geological Sciences, University of Michigan, Ann Arbor, MI, 48109, USA

E-mail: skesler@umich.edu

N. Russell

CaribGold Mines Inc., 1ra. Avenida, No. 1410 Apto. 6, CP 11300 Miramar, Ciudad de La Habana, Cuba

K. McCurdy

Managing Director Citibank, N.A., Global Mining and Metals, 388 Greenwich Street, New York, NY, 10013, USA abruptly in the upper part of the deposits. This change probably reflects boiling of the hydrothermal solutions and partitioning of mercury and tellurium into a rising vapor phase, and it suggests that host rocks overlying the deposits will be anomalous in mercury and tellurium. Comparison to the Broadlands, New Zealand, hydrothermal system supports these inferred depositional processes. It shows that the behavior of arsenic and antimony at Broadlands was different from that at Pueblo Viejo, possibly because the elements were complexed differently in the two ore fluids. Comparison of trace-element abundances at Pueblo Viejo to other highsulfidation epithermal systems shows differences in basemetal, arsenic and mercury abundances which may be related to the depths at which the deposits formed. The results of this study highlight the application and need for quantitative trace-element data from epithermal deposits.

Keywords Epithermal - High sulfidation - Acidsulfate $\cdot$ Trace element $\cdot$ Gold $\cdot$ Pueblo Viejo

\section{Introduction}

Quantitative information on the average abundances and zoning of trace elements in ore deposits is surprisingly scarce. This is unfortunate because ore deposits are important geochemical anomalies for many elements other than those which are mined, and better information on the concentration and zoning of these elements would be useful in genetic studies, exploration, mine planning, and environmental compliance. For example, interpretation of the zoning of mercury may provide information on the distribution and importance of boiling in a hydrothermal system, and on possible geochemical anomalies above an ore zone. Trace elements such as arsenic, lead and selenium are of increasing environmental interest, and better knowledge of their distributions in ore deposits would help in minimizing 
their dispersal into the environment during mining and processing of the ore.

Information on trace-element abundances is particularly scarce for high-sulfidation, or acid-sulfate, preciousmetal deposits, and consists mainly of small-sample averages from Nansatsu (Japan), Rodalquilar (Spain), Paradise Peak (Nevada) and El Indio (Chile; Sidley and Arenada 1986; Hernandez et al. 1989; John et al. 1990; Hedenquist et al. 1994), and generalized descriptions of element abundances and zoning from Goldfield (Nevada) and Yanacocha (Peru; Wilson 1944; Longo 2000). We summarize here comprehensive data on the distribution of gold, silver, copper, zinc, lead, arsenic, antimony, selenium, tellurium, mercury and barium in and surrounding the Moore and Monte Negro ore bodies in the Pueblo Viejo district, Dominican Republic (Fig. 1). Prior information on trace-metal contents of Pueblo Viejo ore came from the study of McCurdy et al. (1986) and from the recovery of byproduct mercury during processing. Additional details about trace-element zoning patterns in the Monte Negro deposit are discussed by Kesler et al. (2003).

Fig. 1 A Location of the Early Cretaceous Los Ranchos Formation in the Dominican Republic on the island of Hispaniola. B Geologic map of the western end of the Los Ranchos Formation outcrop belt, showing major members. C Geologic map of the Pueblo Viejo district, showing geologic relations in the maardiatreme complex (modified from Kesler et al. 1991; Kettler et al. 1992)

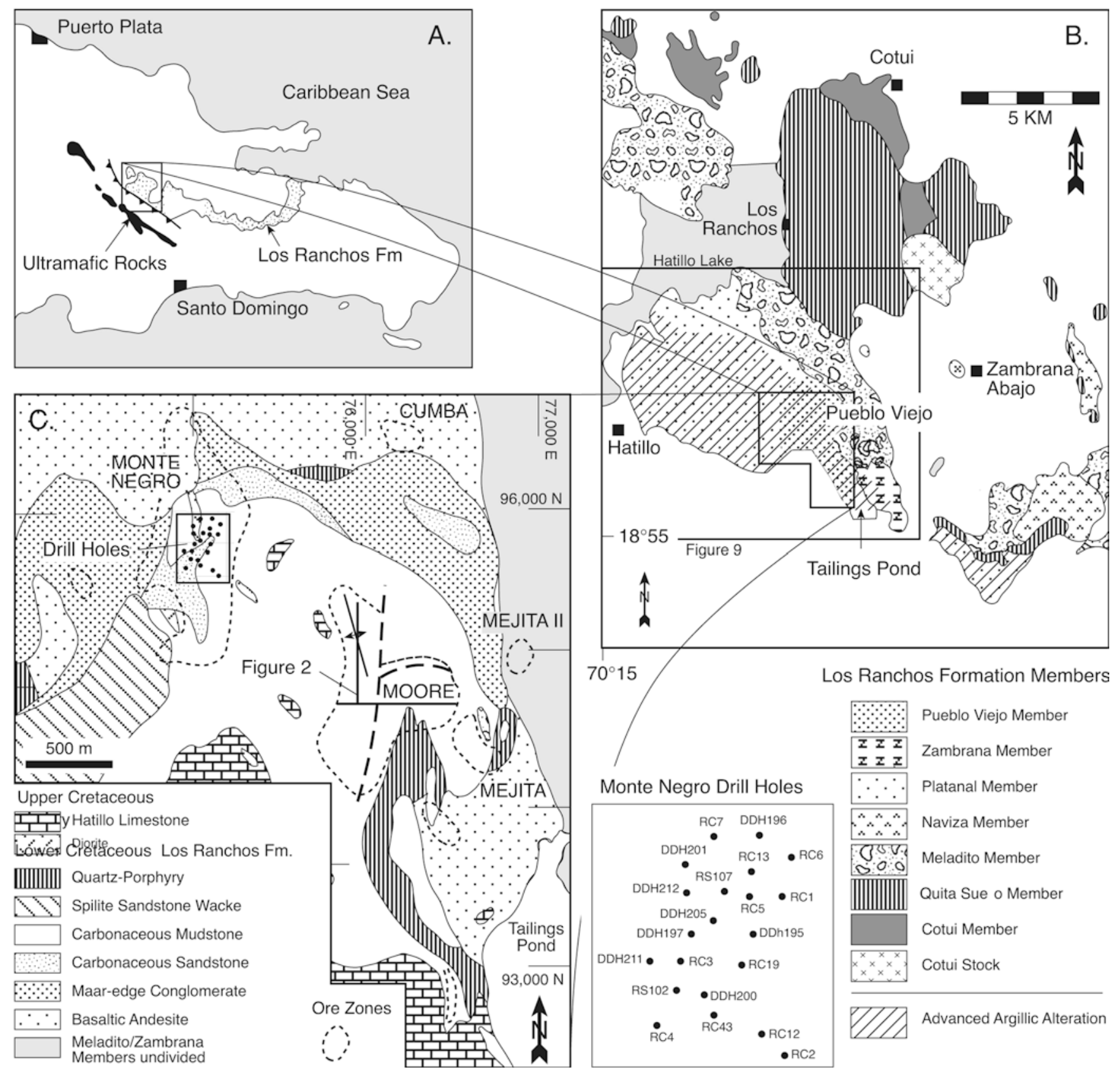


This study is based on analyses of 387 samples representing $10-\mathrm{m}$ vertical intervals in 15 diamond drill holes from the Moore ore body, and 379 samples representing 10-m intervals in 22 diamond drill and rotary holes from the Monte Negro ore body (Table 1). Samples from Moore, which cover the entire volume of rock which underwent advanced argillic alteration and precious-metal mineralization, were analyzed for gold, silver, copper, zinc, lead, arsenic, antimony, selenium, tellurium and mercury. Samples from Monte Negro, which come from the throat of the ore-alteration funnel, were analyzed for gold, silver, copper, zinc, arsenic, antimony, tellurium, mercury and barium. Copper, zinc, gold and silver analyses were carried out on continuous 10-m samples of split core which were assayed at Pueblo Viejo. Lead, arsenic, antimony, mercury, selenium, tellurium and barium concentrations were measured on composite samples consisting of 10 to 20 , separate $10-\mathrm{cm}$ pieces of split drill core taken at intervals of about 0.5 to

Table 1 Location and sampled depths of drill holes from which samples were obtained for this study

\begin{tabular}{|c|c|c|c|c|}
\hline \multirow[t]{2}{*}{ Drill hole } & \multicolumn{2}{|c|}{ Mine coordinates } & \multicolumn{2}{|c|}{$\operatorname{Depth}(\mathrm{m})$} \\
\hline & NS & EW & Start & End \\
\hline \multicolumn{5}{|l|}{ Moore } \\
\hline DDH-159 & 94598 & 76055 & 59 & 239 \\
\hline DDH-160 & 94584 & 76482 & 3 & 215 \\
\hline DDH-161 & 94600 & 76160 & 3 & 227 \\
\hline DDH-162 & 95302 & 76000 & 3 & 237 \\
\hline DDH-165 & 94589 & 76289 & 3 & 279 \\
\hline DDH-166 & 94601 & 75606 & 4 & 293 \\
\hline DDH-167 & 94800 & 76350 & 3 & 199 \\
\hline DDH-168 & 94593 & 76379 & 23 & 243 \\
\hline DDH-170 & 94599 & 75900 & 3 & 207 \\
\hline DDH-171 & 94799 & 76201 & 3 & 309 \\
\hline DDH-173 & 94800 & 75907 & 7 & 177 \\
\hline DDH-174 & 95104 & 76029 & 9 & 229 \\
\hline DDH-175 & 94497 & 75896 & 19 & 293 \\
\hline DDH-182 & 94796 & 75753 & 13 & 195 \\
\hline DDH-185 & 95200 & 75799 & 17 & 329 \\
\hline \multicolumn{5}{|l|}{ Monte Negro } \\
\hline DDH-195 & 95793 & 75108 & 5 & 245 \\
\hline DDH-196 & 95952 & 75110 & 5 & 164 \\
\hline DDH-197 & 95794 & 75012 & 7 & 124 \\
\hline DDH-200 & 95715 & 75030 & 111 & 211 \\
\hline DDH-201 & 95901 & 75001 & 5 & 105 \\
\hline DDH-205 & 95815 & 75045 & 7 & 99 \\
\hline DDH-207 & 95711 & 75163 & 7 & 202 \\
\hline DDH-211 & 95751 & 74946 & 5 & 109 \\
\hline DDH-212 & 95857 & 75000 & 4 & 107 \\
\hline RC-1 & 95852 & 75150 & 2 & 205 \\
\hline $\mathrm{RC}-2$ & 95603 & 75155 & 5 & 205 \\
\hline RC-3 & 95747 & 74993 & 8 & 195 \\
\hline $\mathrm{RC}-4$ & 95649 & 74958 & 5 & 201 \\
\hline RC-5 & 95850 & 75101 & 7 & 97 \\
\hline RC-6 & 95911 & 75166 & 4 & 207 \\
\hline RC-7 & 95945 & 75044 & 3 & 121 \\
\hline RC-12 & 95635 & 75118 & 5 & 201 \\
\hline RC-13 & 95884 & 75104 & 5 & 167 \\
\hline RC-19 & 95744 & 75088 & 6 & 183 \\
\hline RC-43 & 95665 & 75046 & 5 & 145 \\
\hline RS-102 & 95704 & 74986 & 4 & 215 \\
\hline RS-107 & 95861 & 75059 & 5 & 137 \\
\hline
\end{tabular}

$1.0 \mathrm{~m}$ along the $10-\mathrm{m}$ core interval, which were analyzed at Skyline Laboratory in Denver. It should be kept in mind that these analyses do not provide information on the composition of specific stages of mineralization. Instead, they provide a summary of the dispersion of elements which resulted from the combination of all hydrothermal processes which affected the Moore and Monte Negro deposits.

\section{Geologic setting of the Pueblo Viejo district and its ore deposits}

The Pueblo Viejo district consists of several separate deposits, including Moore, Monte Negro, Cumba, Mejita and East Mejita, which consist of oxide ore underlain by sulfide ore. Moore is the largest deposit at Pueblo Viejo, Monte Negro is second and the other deposits are significantly smaller (Kesler et al. 1981; Muntean et al. 1990). About $5 \times 10^{6}$ ounces of gold and $25 \times 10^{6}$ ounces of silver have been mined from the oxide ores. Early estimates of the sulfide reserve totaled about $100 \times 10^{6}$ tonnes averaging about $3 \mathrm{~g} / \mathrm{t} \mathrm{Au}, 23 \mathrm{~g} / \mathrm{t} \mathrm{Ag}$, $0.8 \% \mathrm{Zn}$, and $0.2 \% \mathrm{Cu}$ (Kesler et al. 1981; Muntean et al. 1990), although a more recent estimate places the total oxide plus sulfide resource at about $40 \times 10^{6}$ ounces of gold and $227 \times 10^{6}$ ounces of silver (Nelson 2000). Although most ore that has been mined so far has come from the upper, oxidized part of the ore bodies, some partly oxidized, enriched ore was mined during the 1990s to provide cash flow to government owners who were unable to reach agreement on equity and profit sharing required for development of the much larger sulfide reserve.

Pueblo Viejo is hosted by the upper part of the Early Cretaceous Los Ranchos Formation, the oldest unit in the central Greater Antilles (Bowin 1966; Kesler et al. 1991). Rocks of the Los Ranchos Formation crop out in a belt about $100 \mathrm{~km}$ long that crosses the eastern part of Hispaniola (Fig. 1A). Mapping at the western end of this belt has divided the formation into basal units consisting mainly of locally pillowed flows of seawateraltered basaltic andesite (Cotui Member) and flows, tuffs and shallow intrusions of dacite (Quita Sueño Member), which are overlain by debris flows and volcaniclastic sedimentary rocks of the Meladito Member and unpillowed basaltic andesite of the Platanal and Navisa members (Fig. 1B). The Meladito and Platanal members are cut and partly overlain in one area by volcaniclastic rocks and carbonaceous sedimentary rocks of the Zambrana and Pueblo Viejo members. Radiolarian cherts and thin lenses of limestone interlayered in this sequence indicate that it was deposited during Early Cretaceous time, and abundant land plants in the upper part of the sequence indicate that it was emergent during later phases of volcanism. Circulation of seawater through the Los Ranchos Formation, probably during its formation, led to extensive seawater metamorphism, creating rocks that have been referred to as spilite and 
keratophyre (Kesler et al. 1991). The Los Ranchos Formation, including the Pueblo Viejo ore zones, is overlain unconformably by the Hatillo Formation, a Cenomanian to Albian limestone that formed a fringing reef surrounding the extinct Los Ranchos volcanic island (Fig. 1C).

Mineralization at Pueblo Viejo is hosted mainly by rocks of the Pueblo Viejo Member that fill a basin in the upper part of the Los Ranchos Formation. The western and northern sides of this basin are well defined by conglomerate, the southern side is covered by the younger Hatillo Formation, and the eastern side appears to grade into volcanic and volcaniclastic rocks of the Meladito and Zambrana members (Fig. 1C). In the area of the Moore deposit, where relations are best known, fragmental rocks consisting mainly of volcanic debris with local fragments of intrusive rock fill the lower part of the basin (Fig. 2A). These grade upward into carbonaceous sandstones and finally fine-grained carbonaceous mudstones. At least one Platanal Member flow, which appears to have been emplaced during filling of the basin, rests on top of the sandstone and beneath the fine-grained mudstones. The basin, which has been interpreted to be a diatreme-maar complex (Sillitoe and Bonham 1984; Russell and Kesler 1991; Kesler 1998), also contains a large mass of fragmental quartz-porphyry referred to as the "quartz-eye unit" by Kesler and Russell (2000). Although it has been suggested that this quartz-porphyry mass was intruded into its present position (Nelson 2000), the unit is strongly fragmental and drill data show that it is not underlain by a root or feeder zone. Russell and Kesler (1991) suggested that it consists of material ejected during formation of the proposed maar-diatreme complex.

\section{Alteration and ore mineralogy of the Pueblo Viejo ore bodies}

Both the Moore and Monte Negro ore bodies form funnel-shaped zones that can be delineated by the transition from advanced argillic alteration assemblages
Fig. 2A, B Isometric projection through the Moore ore body on the eastern side of the maardiatreme complex at Pueblo Viejo, showing $\mathbf{A}$ the distribution of major geologic units, and $\mathbf{B}$ the hydrothermal alteration. The volume of rock altered to alunite, pyrophyllite, and kaolinite and showing intense silicification is referred to in the text as the zone of "advanced argillic alteration" to distinguish it from the surrounding rocks containing alteration assemblages including calcite, epidote, chlorite and albite that formed by seawater metamorphism during emplacement of the Los Ranchos Formation host rocks. Drill holes used in this study that fall on these sections are shown in $\mathbf{B}$; drill-hole coordinates, depths and samples used in the study are listed in Table 1

\section{Moore Orebody}

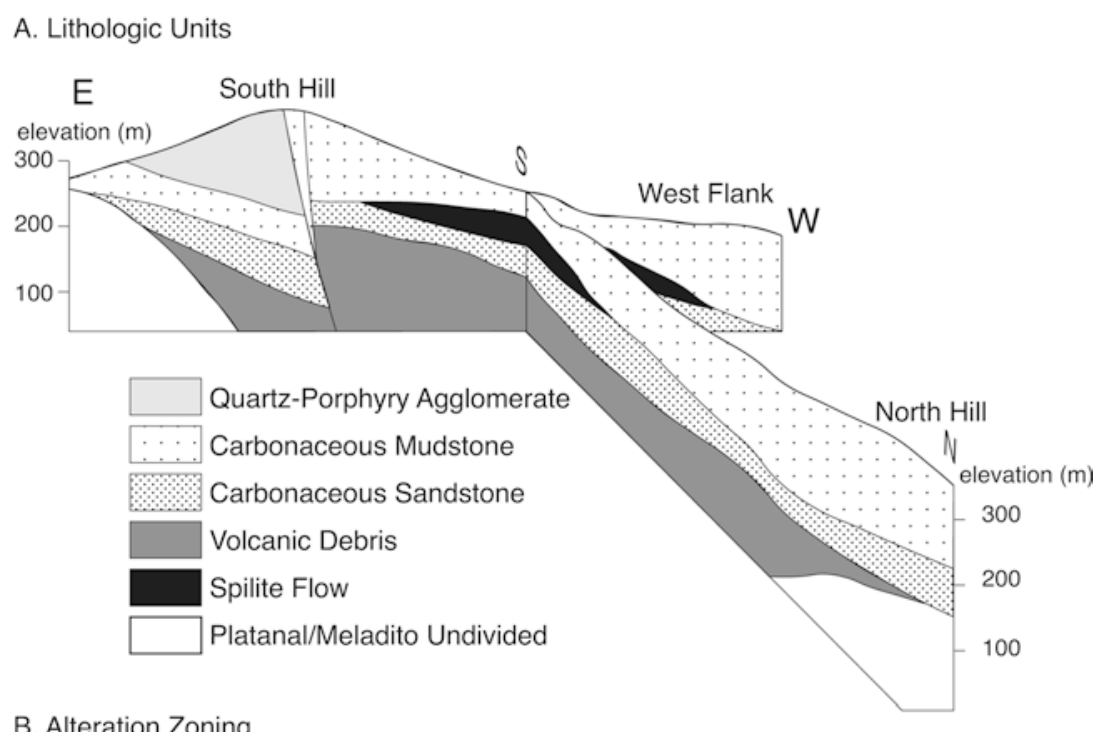

B. Alteration Zoning

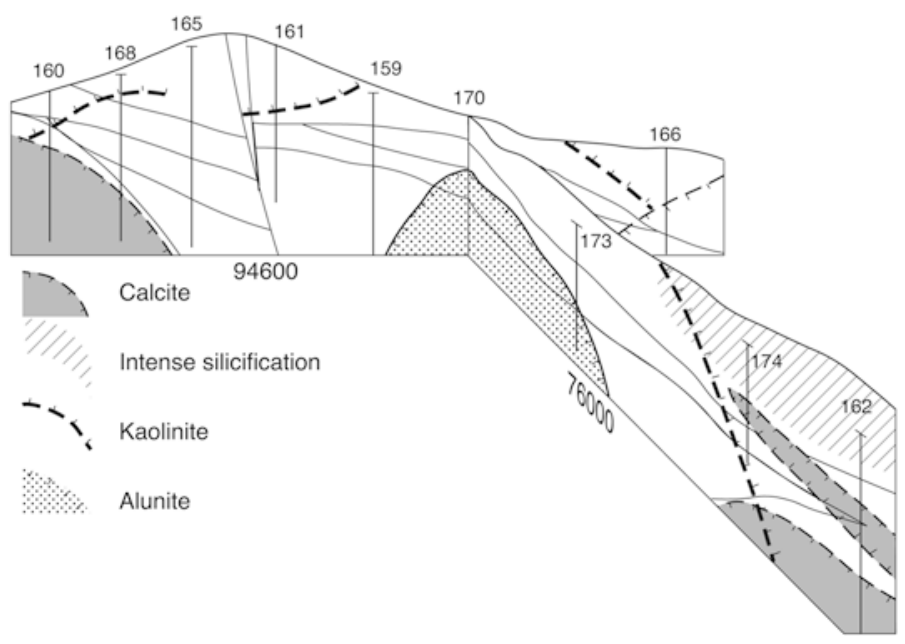


to the chlorite-albite-calcite-epidote assemblage that formed during seawater metamorphism of the Los Ranchos Formation (Kesler et al. 1981). At Moore, coexisting alunite and pyrite in the deep, central part of the ore body grade outward and upward through pyrophyllite-bearing assemblages to kaolinite and intense silicification near the top of the system (Fig. 2). Gold is hosted mainly by irregular veins that cut the upper part of the funnel-shaped system, although some is disseminated in rock that has undergone advanced argillic alteration. Muntean et al. (1990) showed that mineralization and alteration in the Monte Negro ore body were products of a three-stage process. The first stage involved formation of pervasive, deep alunite + quartz + pyrite and overlying kaolinite + pyrite + silica alteration. This was overprinted by deep, pervasive and vein-hosted pyrophyllite \pm diaspore that graded upward into massive silicification in the upper part of the system, and then by later veinlets containing sulfide minerals and precious metals that are thought to have formed in response to hydraulic fracturing. Gold was deposited during early alteration, and then remobilized and augmented during later vein formation and alteration (Muntean et al. 1990). Silica was probably deposited as quartz in the deeper parts of the systems but may have had other forms originally at shallower levels (Muntean et al. 1990).

Muntean et al. (1990) used mineral equilibria, isotopic and limited fluid-inclusion evidence to show that the ore fluid in the Monte Negro deposit had maximum temperatures of 200 to $300{ }^{\circ} \mathrm{C}$, pH between 1.5 and 2.5 , $\mathrm{f}_{\mathrm{O} 2}$ in the upper part of the pyrite stability field, and contained about $1 \mathrm{~mol} \mathrm{NaCl}$ and $0.01 \mathrm{~mol} \mathrm{H}_{2} \mathrm{~S}$. Vennemann et al. (1993) used stable-isotope evidence to show that mineralizing fluids at Pueblo Viejo were almost exclusively of magmatic origin, a condition possible because the system was surrounded and isolated by rock containing gypsum-filled fractures. The upward transition from deep alunite and/or pyrophyllite to shallow kaolinite and intense silicification in both deposits probably reflects a relatively steep temperature gradient, suggesting an epithermal environment, although exact depths are poorly constrained. Because mineralization took place before deposition of the Hatillo Formation fringing reef, the only overburden present at the time of mineralization was the upper Los Ranchos Formation (Bowin 1966; Russell and Kesler 1991). Currently exposed, upper Los Ranchos Formation rocks are about $200 \mathrm{~m}$ thick and can be combined with the 300 to $400 \mathrm{~m}$ of mineralized rock to give an overburden thickness of about 500 to $600 \mathrm{~m}$ over the deepest parts of the deposits. This depth is adequate to keep water in only the lower part of the 200 to $300^{\circ} \mathrm{C}$ range noted above on the boiling curve, although even greater depths are required for solutions containing dissolved gas (Haas 1971; Henley et al. 1984).

This suggests, in turn, that the diaspore-pyrophyllite assemblage indicating temperatures of $300{ }^{\circ} \mathrm{C}$ may not have been deposited in equilibrium (Hemley et al. 1980; Muntean et al. 1990).

\section{Mineralogy, abundance and correlation of trace elements}

Mineralogy of the sulfide zone

The most abundant main-stage sulfide ore minerals at Pueblo Viejo are pyrite, sphalerite, and enargite. Pyrite formed matching, typically botryoidal layers on opposite sides of veins. The centers of veins are filled mainly by iron-poor sphalerite $(0.38 \mathrm{~mol} \% \mathrm{FeS})$ that is found throughout the deposits, and enargite that is found at deeper levels of the deposits (Kesler et al. 1981; Muntean et al. 1990). Some enargite is intergrown with equal amounts of famatinite, which suggests that they formed in the two-phase field in the $\mathrm{Cu}-\mathrm{As}-\mathrm{Sb}-\mathrm{S}$ system (Feiss 1974; Posfai and Buseck 1998), and enargite also coexists with apparently primary covellite in several areas far below the oxide zone. Quartz formed coatings on pyrite in veins, and the centers of some veins are filled by quartz, barite and pyrophyllite. Alteration surrounding veins consists mainly of silicification and local pyritization that extend outward about one vein width into wall rocks. Pyrophyllite veinlets and masses cut some veins.

Tennantite-tetrahedrite with $\mathrm{As} / \mathrm{Sb}$ atomic ratios of 3:1 to $10: 1$ is the most common minor mineral in the veins. At the Moore deposit it is in fractures that cut enargite, and at the Monte Negro deposit it coexists with sphalerite and pyrite (Muntean et al. 1990). Tennantite is not stable with enargite and covellite at about $300{ }^{\circ} \mathrm{C}$ (Maske and Skinner 1971). Inclusions of galena, stibnite, colusite and $\mathrm{Pb}-\mathrm{As}-\mathrm{Sb}$ sulfosalts, with compositions close to those of bournonite, zinckenite and boulangerite, are found as inclusions in enargite and, less commonly, in sphalerite and pyrite (Kesler et al. 1981; Muntean et al. 1990). Inclusions of precious-metalbearing minerals, including gold-rich electrum $(\mathrm{Ag}+\mathrm{Cu}<5 \mathrm{wt} \%)$, argentite $\left(\mathrm{Ag}_{2} \mathrm{~S}\right)$ and tellurides with compositions close to calaverite or krennerite $\left(\mathrm{AuTe}_{2}\right)$ and hessite $\left(\mathrm{Ag}_{2} \mathrm{Te}\right)$, are concentrated along growth zones in pyrite (Kesler et al. 1981). Late-stage vugs and veins in the central part of the Moore ore body contain fine-grained quartz with native sulfur and/or realgar. Electron microprobe analyses show that tennantite contains as much as several percent zinc and silver, whereas enargite contains only $\leq 0.1 \% \mathrm{Zn}$ (Muntean et al. 1990). Lead-bearing sulfosalts contain about $0.5 \% \mathrm{Ag}$ and no detectable zinc. No mercury-bearing minerals were found, but analyses of mineral separates indicate that mercury is concentrated in sphalerite relative to pyrite and enargite (Table 2). Trace levels of tellurium $(<0.03 \mathrm{wt} \%)$ were detected in electron microprobe analyses of enargite.

Paragenetic relations of vein minerals show that pyrite formed first and was followed by sphalerite and enargite with local famatinite and covellite. Most of the 
other minerals formed either as small inclusions in these major minerals or by exsolution from enargite and sphalerite. Tennantite-tetrahedrite partially replaced enargite and was deposited in equilibrium with some pyrite and sphalerite. These paragenetic relations apply only to the sulfide mineral-bearing veins, which followed widespread disseminated mineralization at the Monte Negro deposit (Muntean et al. 1990). A few grains of

Table 2 Arsenic and mercury contents of ore mineral separates from the Moore deposit

\begin{tabular}{lll}
\hline Sample & $\operatorname{As}(\%)$ & $\operatorname{Hg}(\mathrm{ppm})$ \\
\hline Pyrite & & \\
DDH-112-15 & 0.11 & 1.5 \\
DDH-61-53 & 0.11 & 2.0 \\
DDH-99-19.5 & 0.02 & 2.5 \\
DDH-100-16 & 0.01 & 3.0 \\
T-6-3-A & 0.04 & 100 \\
T-6-3-B & 0.04 & 70 \\
Sphalerite & & \\
DDH-92-47 & 0.04 & 140 \\
DDH-96-25 & 0.02 & 350 \\
T-6-2 & 0.04 & 200 \\
T-6-3 & 0.04 & 300 \\
Enargite & & \\
DDH-93-28 & 13.0 & 5.0 \\
DDH-93-23 & 13.6 & 6.5 \\
DDH-99-19.5 & 16.6 & 30 \\
\hline
\end{tabular}

native gold have been found with pyrite that is part of this early disseminated mineralization, but no other trace-element-rich minerals have been clearly assigned to this phase of mineralization. Late quartz veins containing realgar and native sulfur cut sulfide mineral-bearing veins in some deep parts of the Moore deposit.

Additional insights into the mineralogical setting of the trace elements can be obtained from correlations between log-transformed element pairs. Element pairs from Moore have generally higher correlation coefficients than do element pairs from Monte Negro (Table 3). Correlation coefficients for the same element pair from the two deposits are strongly correlated $(\mathrm{r}=0.57, N=28)$, indicating that element associations are similar in the two deposits. As discussed below, the vertical zoning of elements at Moore and Monte Negro differs, with concentrations of most elements at Moore increasing steadily upward. By contrast, concentrations of most elements at Monte Negro increase upward to depths of about 50 to $70 \mathrm{~m}$, well below the oxide-sulfide transition, and then decrease gradually above that. All correlation coefficients calculated for Monte Negro element pairs below 70-m depth, where concentrations increase with decreasing depth, are considerably higher than those calculated for the entire Monte Negro dataset and are similar to those obtained for Moore.

A frequency plot of all correlation coefficients from Table 3 shows that they can be divided at a value of

Table 3 Correlation coefficients (r) for trace and major ore elements in the Pueblo Viejo district.Correlations were calculated for elements transformed to $\log _{10}$ values because all elements show highly skewed populations that are made significantly more normal by log transformation (n.d. not determined)

\begin{tabular}{|c|c|c|c|c|c|c|c|c|c|c|}
\hline & $\mathrm{Au}$ & $\mathrm{Ag}$ & $\mathrm{Cu}$ & $\mathrm{Zn}$ & $\mathrm{Pb}$ or $\mathrm{Ba}$ & As & $\mathrm{Sb}$ & $\mathrm{Hg}$ & $\mathrm{Te}$ & $\mathrm{Se}$ \\
\hline \multicolumn{11}{|l|}{ Moore } \\
\hline & $\mathrm{Au}$ & $\mathrm{Ag}$ & $\mathrm{Cu}$ & $\mathrm{Zn}$ & $\mathrm{Pb}$ & As & $\mathrm{Sb}$ & $\mathrm{Hg}$ & $\mathrm{Te}$ & $\mathrm{Se}$ \\
\hline $\mathrm{Au}$ & 1.00 & $0.66^{\mathrm{a}}$ & 0.26 & $0.51^{\mathrm{a}}$ & 0.31 & 0.33 & 0.39 & $0.64^{\mathrm{a}}$ & 0.44 & 0.26 \\
\hline $\mathrm{Ag}$ & & 1.00 & $0.53^{\mathrm{a}}$ & $0.56^{\mathrm{a}}$ & 0.30 & $0.52^{\mathrm{a}}$ & $0.57^{\mathrm{a}}$ & $0.64^{\mathrm{a}}$ & $0.59^{\mathrm{a}}$ & 0.34 \\
\hline $\mathrm{Cu}$ & & & 1.00 & 0.27 & 0.23 & $0.61^{\mathrm{a}}$ & $0.64^{\mathrm{a}}$ & 0.32 & 0.43 & 0.09 \\
\hline $\mathrm{Zn}$ & & & & 1.00 & 0.24 & 0.33 & 0.36 & $0.58^{\mathrm{a}}$ & 0.41 & 0.21 \\
\hline $\mathrm{Pb}$ & & & & & 1.00 & 0.22 & 0.20 & 0.26 & 0.16 & -0.02 \\
\hline As & & & & & & 1.00 & $0.77^{\mathrm{a}}$ & $0.57^{\mathrm{a}}$ & $0.61^{\mathrm{a}}$ & 0.26 \\
\hline $\mathrm{Sb}$ & & & & & & & 1.00 & $0.63^{\mathrm{a}}$ & $0.67^{\mathrm{a}}$ & 0.38 \\
\hline $\mathrm{Hg}$ & & & & & & & & 1.00 & $0.59^{\mathrm{a}}$ & $0.48^{\mathrm{a}}$ \\
\hline $\mathrm{Te}$ & & & & & & & & & 1.00 & 0.42 \\
\hline $\mathrm{Se}$ & & & & & & & & & & 1.00 \\
\hline \multicolumn{11}{|c|}{ Monte Negro } \\
\hline & $\mathrm{Au}$ & $\mathrm{Ag}$ & $\mathrm{Cu}$ & $\mathrm{Zn}$ & $\mathrm{Ba}$ & As & $\mathrm{Sb}$ & $\mathrm{Hg}$ & $\mathrm{Te}$ & $\mathrm{Se}$ \\
\hline $\mathrm{Au}$ & 1.00 & $0.60^{\mathrm{a}}$ & 0.18 & 0.09 & 0.12 & $0.43^{\mathrm{b}}$ & $0.33^{\mathrm{b}}$ & $0.42^{\mathrm{b}}$ & 0.32 & n.d. \\
\hline $\mathrm{Ag}$ & & 1.00 & 0.37 & 0.10 & 0.15 & 0.33 & $0.36^{\mathrm{b}}$ & 0.30 & 0.36 & n.d. \\
\hline $\mathrm{Cu}$ & & & 1.00 & 0.13 & 0.06 & 0.29 & 0.32 & 0.14 & $0.25^{\mathrm{b}}$ & n.d. \\
\hline $\mathrm{Zn}$ & & & & 1.00 & 0.28 & 0.32 & 0.16 & $0.39^{\mathrm{b}}$ & 0.01 & n.d. \\
\hline $\mathrm{Ba}$ & & & & & 1.00 & 0.12 & 0.26 & 0.29 & 0.05 & n.d. \\
\hline As & & & & & & 1.00 & $0.61^{\mathrm{a}}$ & $0.56^{\mathrm{a}}$ & 0.31 & n.d. \\
\hline $\mathrm{Sb}$ & & & & & & & 1.00 & $0.55^{\mathrm{a}}$ & $0.41^{\mathrm{b}}$ & n.d. \\
\hline $\mathrm{Hg}$ & & & & & & & & 1.00 & $0.29^{\mathrm{b}}$ & n.d. \\
\hline $\mathrm{Te}$ & & & & & & & & & 1.00 & n.d. \\
\hline $\mathrm{Se}$ & & & & & & & & & & n.d. \\
\hline
\end{tabular}

${ }^{a}$ Values in the high-value population in Fig. 3

${ }^{b}$ Values (Monte Negro only) indicate those element pairs with correlation coefficients higher than 0.5 (and therefore in the high-value population in Fig. 3) when data from above about $70 \mathrm{~m}$ are excluded (as discussed in the text). At the Moore deposit, correlations are significant at the $99 \%$ level for all element pairs except lead-selenium and copper-selenium. At the Monte Negro deposit, correlations are significant at the $99 \%$ level for all element pairs except zinc-tellurium, zinc-gold, zinc-silver and copper-barium 


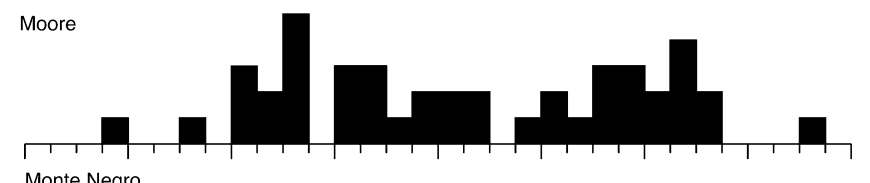

Monte Negro

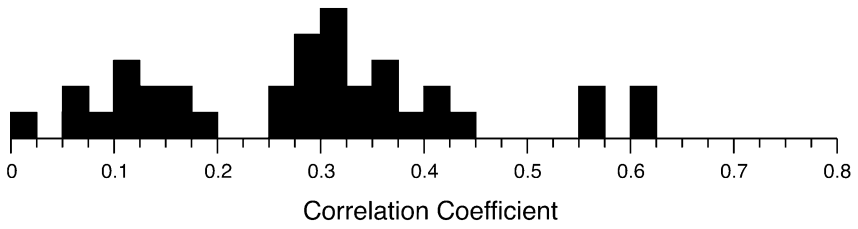

Fig. 3 Histogram showing correlation coefficients for log-normalized trace-element pairs from Table 3

about 0.45 into two populations, one with a mode at about 0.25 to 0.35 and another with a mode of approximately 0.60 (Fig. 3). Most of the element pairs that fall in the high population are from Moore. Only four element pairs from the total Monte Negro dataset have correlation coefficients above 0.45 , but another eight element pairs in the Monte Negro data from below $70 \mathrm{~m}$ are higher than 0.45 (Table 3). Element pairs that make up the high-value population (identified by superscripts a, b in Table 3) appear to reflect control by one or two common minerals. For example, high correlations between gold and silver and somewhat lower correlations of tellurium with silver and gold indicate that most gold and silver are in electrum rather than tellurides. High correlations between arsenic and copper, antimony and copper, and arsenic and antimony indicate that these elements are mainly in enargite and tennantite. Tellurium also shows a high degree of correlation with antimony and arsenic, indicating that most tellurium is in tennantite, rather than the gold and silver telluride minerals mentioned above. Mercury has high correlations with gold and silver, indicating its presence in electrum; with zinc, reflecting its substitution for zinc in sphalerite; and with antimony, indicating that it follows zinc into tetrahedrite. The smaller number of high correlation coefficients from Monte Negro, even when data from below $70 \mathrm{~m}$ are used, reflects the lack of enargite-bearing veins in that system, and the fact that some large sphalerite veins are relatively low in gold, silver and mercury.

These results indicate that gold, silver, zinc, arsenic, and antimony are hosted mainly by minerals in that they are major elements, including electrum, sphalerite, enargite, and tetrahedrite-tennantite. By contrast, most mercury and tellurium occur as minor phases in these minerals, specifically electrum, tennantite and sphalerite for mercury, and tennantite for tellurium. Selenium at the Moore deposit correlates most strongly with mercury, which does not provide much insight into its mineralogical setting. Its other high correlations are with tellurium and antimony, however, suggesting that it follows mercury into tennantite. Barium at the Monte Negro deposit does not correlate strongly with the other elements, confirming that it is found only in barite.
Mineralogy of the oxide zone

Oxidation of the upper part of the Moore and Monte Negro ore bodies changed the mineralogical residence of all of the elements except barium, which remained as barite in the oxide zone. Copper and zinc were almost completely removed from the oxide zone, and some of the copper was concentrated in a discontinuous, covellite-bearing enriched zone immediately below the oxide interface (Russell et al. 1981). Silver was remobilized during oxidation, and some of it concentrated immediately below the oxide zone in an enriched zone containing stromeyerite $(\mathrm{Ag}, \mathrm{Cu})_{2} \mathrm{~S}$ and aguilarite $\left(\mathrm{Ag}_{2}(\mathrm{~S}, \mathrm{Se})\right)$. Silver also remained in the oxide zone where it is found in cerargyrite $(\mathrm{AgCl})$, embolite $(\mathrm{Ag},(\mathrm{Br}, \mathrm{Cl}))$ and iodobromite (2AgCl.2AgBr.2AgI). Minor native silver has been found in a few places at the oxide-sulfide interface. Mercury in the oxide zone has been observed in calomel $\left(\mathrm{Hg}_{2} \mathrm{Cl}_{2}\right)$. Gold does not appear to have been remobilized during oxidation, and forms porous grains from that silver has been leached (Russell et al. 1981).

Oxidation was not accompanied by significant reduction in volume; rock textures including original layering are well preserved in oxide ore. Comparison of average compositions of sulfide and oxide ores at Moore (Table 4) shows that only copper and zinc are significantly depleted in the oxide zone. Abundances of arsenic, antimony, silver, selenium and lead are slightly enriched in the oxide zone, whereas tellurium and mercury are strongly enriched. The depletion in copper and zinc is clearly related to destruction of sulfide minerals during oxidation. Enrichment of the other elements is probably not due to loss of mass during oxidation or original differences in composition of primary ores. Densities of oxide ore are probably about 2 , compared to about 3 for unweathered ore, a change that would increase immobile-element concentrations by only about $50 \%$. All of the enriched elements show a greater increase than this. In view of the petrographic and geochemical evidence that gold was not enriched by downward migration during oxidation (Russell et al. 1981), this indicates that much of the difference between oxide and sulfide metal endowment reflects original vertical zoning in the hydrothermal system, as discussed below. It is also not likely that mercury and other elements were leached from overlying (now eroded) rocks during oxidation or late stages of hydrothermal activity and transported downward into the present ore zone, because they are found largely as substituting elements in main-stage ore minerals, not in late-stage encrustations.

\section{Concentration and zoning of trace elements}

Concentration of trace elements relative to crustal averages

Although ore at Pueblo Viejo was mined for gold and silver, many other pathfinder elements were also 
Table 4 Average compositions and enrichments of ore elements in the Moore and Monte Negro deposits at Pueblo Viejo (n.a. not analyzed, $n . d$. not determined)

\begin{tabular}{|c|c|c|c|c|c|c|}
\hline \multirow[t]{2}{*}{ Element $^{\mathrm{a}}$} & \multicolumn{4}{|l|}{ Moore } & \multicolumn{2}{|l|}{ Monte Negro } \\
\hline & $\begin{array}{l}\text { Oxide mean } \\
(\mathrm{ppm})\end{array}$ & Degree of enrichment & $\begin{array}{l}\text { Sulfide mean } \\
(\mathrm{ppm})\end{array}$ & Degree of enrichment & $\begin{array}{l}\text { Sulfide mean } \\
(\mathrm{ppm})\end{array}$ & Degree of enrichment \\
\hline $\mathrm{Au}$ & 2.5 & 625 & 1.5 & 375 & 3 & 750 \\
\hline $\mathrm{Ag}$ & 17.7 & 253 & 8.7 & 124 & 20 & 286 \\
\hline $\mathrm{Te}$ & 19.6 & 19,600 & 3.1 & 3,100 & 16 & 16,000 \\
\hline $\mathrm{Se}$ & 5.6 & 11 & 2.6 & 5 & n.d. & n.d. \\
\hline As & 690 & 383 & 368 & 204 & 486 & 270 \\
\hline $\mathrm{Sb}$ & 79 & 395 & 51 & 255 & 247 & 1,235 \\
\hline $\mathrm{Cu}$ & 100 & 2 & 800 & 15 & 3,489 & 63 \\
\hline $\mathrm{Zn}$ & 100 & 1 & 3,400 & 49 & 2,018 & 29 \\
\hline $\mathrm{Pb}$ & 301 & 24 & 100 & 8 & n.a. & n.a. \\
\hline $\mathrm{Hg}$ & 32 & 400 & 1.8 & 23 & 10 & 126 \\
\hline $\mathrm{Ba}$ & n.a. & n.a. & n.a. & n.a. & 997 & 2 \\
\hline
\end{tabular}

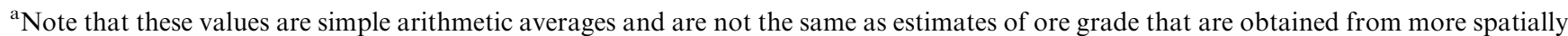
controlled methods. In addition, values for Moore represent the entire volume of mineralized and altered rock, whereas those for Monte Negro represent only the central funnel of the system

concentrated by the hydrothermal system. An indication of the degree of concentration is shown by comparison of the average concentration of each element in the sulfide zone to the average concentration of that element in high-calcium granites, which are most similar in composition to the quartz-porphyry and the Cotui stock with that mineralization is probably genetically associated (Turekian and Wedepohl 1961). As can be seen in Table 4, enrichment factors at Moore fall into three groups. Tellurium is by far the most concentrated element, with an enrichment factor relative to high-calcium granite of about 3,100. Gold, antimony, arsenic and silver have relatively similar enrichment factors ranging from 375 to 124 , and zinc, mercury, copper, lead and selenium have significantly lower enrichment factors between 49 and 5. The enormous difference in enrichment factors for tellurium and selenium in the Moore deposit highlights their very different geochemical behaviors in ore deposits, where tellurium generally forms more minerals than does selenium (Afifi et al. 1988; Simon et al. 1997).

Element enrichment factors at the Monte Negro deposit (Table 4) show a similar sequence from tellurium, which is most concentrated, through antimony, gold, silver, arsenic, mercury, copper, zinc and finally to barium. Barium has an enrichment factor of $\leqq 2$ in the Monte Negro deposit, and appears to form a weak halo around the deposit (Fig. 5 in Russell et al. 1986). This low level of enrichment suggests that much of the barite seen in the deposit was liberated from feldspars during advanced argillic alteration, rather than being introduced by the mineralizing fluid. Support for this interpretation is seen in the fact that barium abundances at Monte Negro do not correlate with other elements such as gold, arsenic and tellurium that were obviously introduced into the system (Fig. 4). This generalization is further supported by data of Hedenquist et al. (1994)
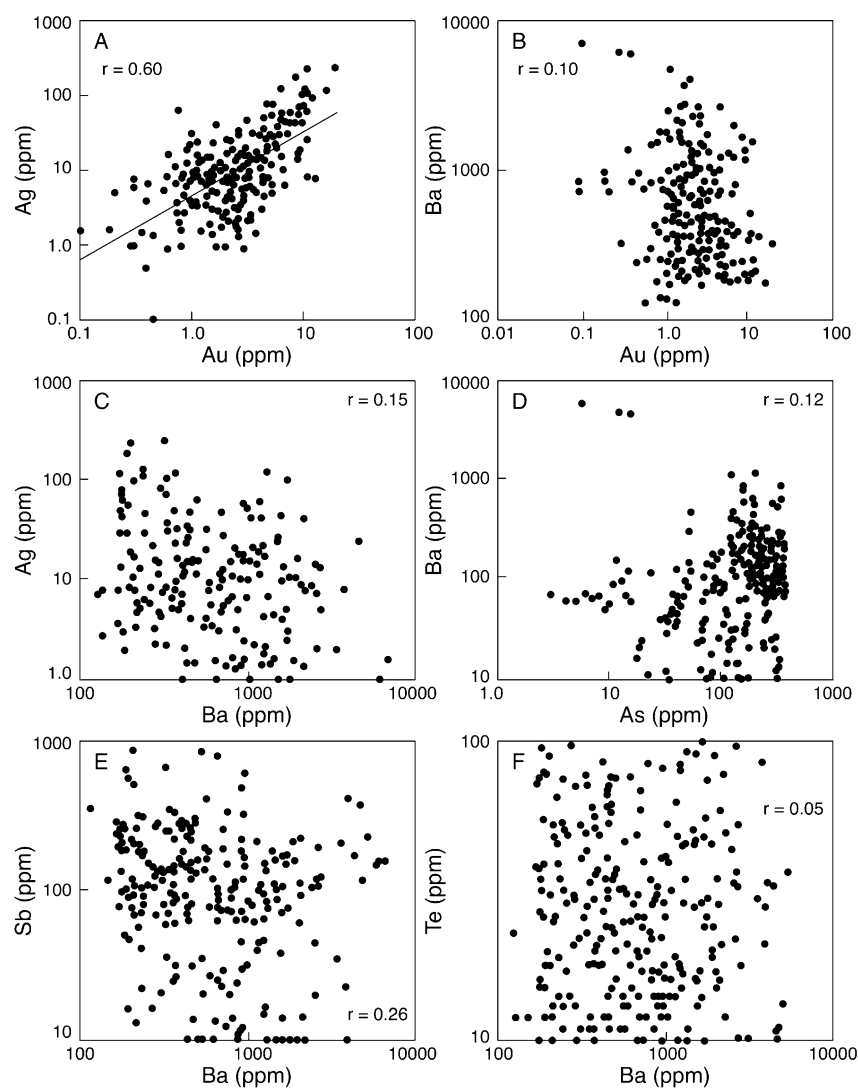

Fig. 4A-F Plots showing correlation between gold and silver, and between barium and other elements in the Monte Negro deposit: A $\mathrm{Au}-\mathrm{Ag}, \mathbf{B} \mathrm{Au}-\mathrm{Ba}, \mathbf{C} \mathrm{Ag}-\mathrm{Ba}, \mathbf{D} \mathrm{As}-\mathrm{Ba}, \mathbf{E ~ S b}-\mathrm{Ba}, \mathbf{F} \mathrm{Te}-\mathrm{Ba}$. Note that the $\mathrm{Au}-\mathrm{Ag}$ plot $(\mathbf{A})$ shows a high correlation whereas the Ba-metal plots (B-F) do not

that show that average barium concentrations in the Nansatsu deposits are actually lower than average highcalcium granite, even though barite is a stable phase in the ore assemblage. 


\section{Zoning of trace elements}

Information on lateral zoning of trace elements in the deposits could be obtained only at the Moore deposit, where data covered the entire hydrothermally altered zone. Average values for each element over the entire vertical length of each hole in the sulfide zone were contoured to look for metal zoning relative to the possible feeder zone recognized by Kesler et al. (1981) and shown on Fig. 5. This possible feeder zone contains the deepest pyrophyllite and shallowest alunite in the deposit, both of that are in the throat of the funnel-shaped ore zone (Figs. 2 and 5). Copper values of 100s$1,000 \mathrm{~s} \mathrm{ppm}$ coincide with this possible feeder zone (Fig. 11 in Kesler et al. 1981). The vertically summed distribution of gold, copper and other metals is not clearly zoned with respect to this possible feeder zone, although the trace-element abundance contours do reflect the correlations noted above among zinc and mercury in sphalerite, and tellurium, antimony, arsenic and copper in enargite and tetrahedrite-tennantite. The contours also show that elements are dispersed differently. Zinc, mercury and lead values above the 75th percentile cover about $25 \%$ of the deposit area whereas copper, antimony, and arsenic values above the 75th percentile cover only about $5 \%$ of the area. The pattern for these last three elements is strongly influenced by a massive enargite-pyrite lens that was encountered in DDH 161 in the southern part of the ore body.

The isometric projection of the Moore ore body shows that highest metal concentrations define large, horizontal zones in the upper part of the system, which coincide mainly with the fine-grained carbonaceous sediment unit and extend locally into the spilite flow and underlying carbonaceous sandstones (Fig. 6). Highest concentrations for many trace metals in the Monte Negro deposit show an even stronger tendency to form large, horizontal zones in the upper part of the mineralized zone (Kesler et al. 2003). In both deposits, highest concentrations of most ore-related elements are found in and just below the zones of strong silicification that cap the deposits.

Figure 7 shows the vertical zoning of elements in the Moore deposit. Because the deposit was tilted at least $10^{\circ}$ to the southwest (Fig. 1), drill-hole elevations differ slightly from their original positions. However, most points are within $30 \mathrm{~m}$ of their original level relative to one another, which is not enough to obscure the obvious increase in concentrations of all elements, except copper, upward through the deposit (Fig. 7). Correlation coefficients for plots of element concentration versus depth, except copper, are statistically significant at greater than 99\% confidence, and correlations with depth for gold, zinc, selenium, and silver would probably be even higher if the analytical detection limit had allowed analysis of samples with lower abundances. By far the best correlation with depth is seen for mercury, which increases in average concentration by about two orders of magnitude from about $50 \mathrm{ppb}$ at the bottom of the presently
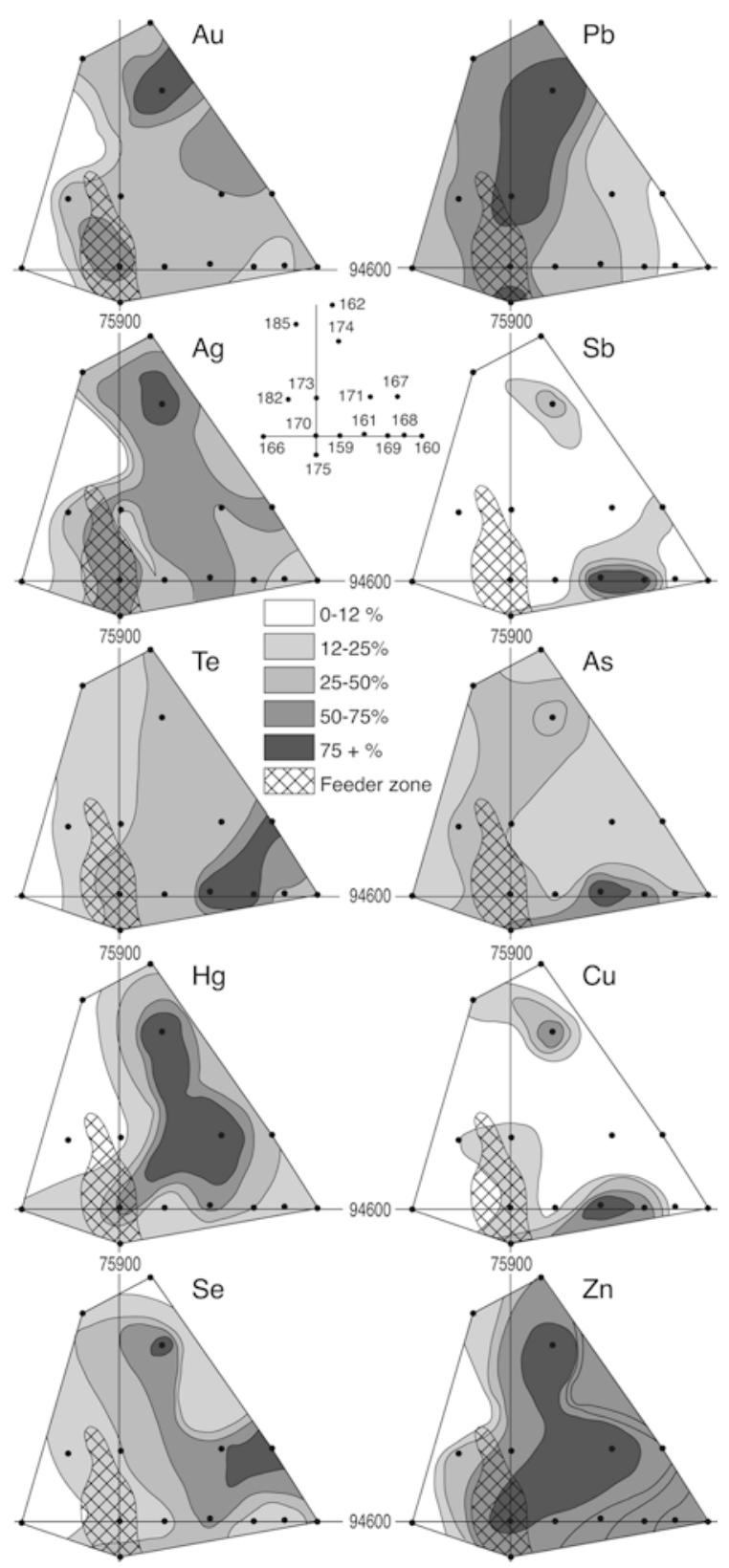

Fig. 5 Lateral distribution of trace elements in the Moore deposit (contours based on average metal content for the entire vertical length of each hole in the sulfide zone). The feeder zone, which is the area of deepest pyrophyllite and shallowest alunite in the deposit (as discussed in the text), is in the throat of the funnelshaped hydrothermal alteration zone (Fig. 2). Holes used are shown in Fig. 2. Contours are open at ends of some sections because the mineralized zone continues a short distance beyond the section

known system to about 5,000 ppb at the top (Fig. 7). Most other elements increase in concentration upward by about one order of magnitude.

Oxide-zone samples clearly are not a major factor in establishing these correlations because they reach depths of only a few tens of meters, and because the concentration of most elements increases gradually across the oxide-sulfide interface. Mercury is the only exception to 


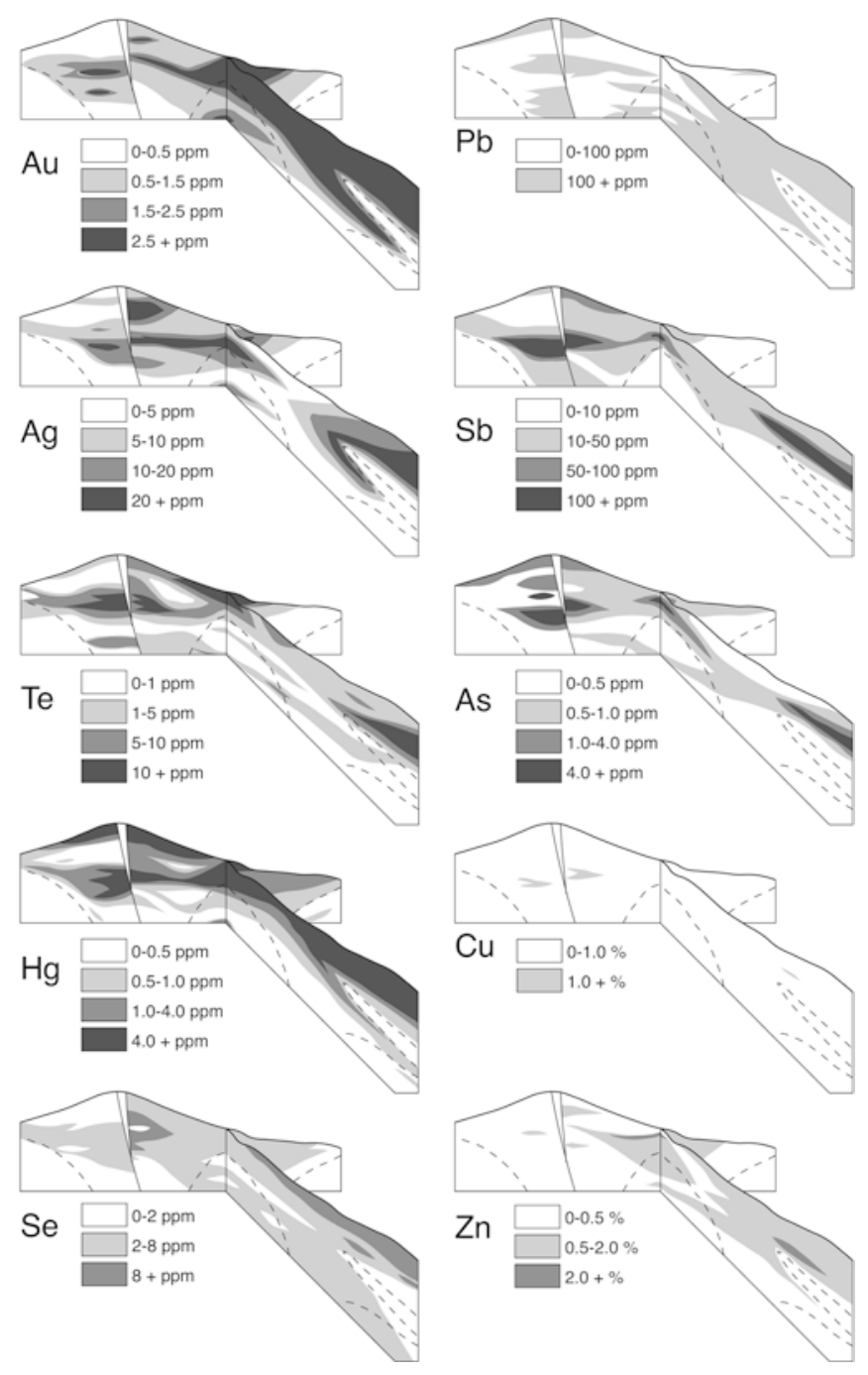

Fig. 6 Distribution of trace elements relative to geologic features in isometric projection (Fig. 2) of the Moore ore body. Dashed lines show outlines of alteration zones from Fig. 2

this rule, changing from values of about $1,000 \mathrm{ppb}$ to values as high as $8,000 \mathrm{ppb}$ just below the oxide-sulfide interface (Fig. 7A). This change is not a function of oxidation because the increase in mercury concentration is far more than could be accounted for by in-situ enrichment due to volume loss or other aspects of the oxidation process, and samples from the sulfide zone also have high values. This abrupt increase probably reflects the original mercury distribution in the Moore hydrothermal system, as discussed further below.

At Monte Negro, concentrations of gold, arsenic, antimony and silver also increase upward, but reach maximum values at depths of about 50 to $70 \mathrm{~m}$ and decrease in abundance upward from that level (Fig. 8). This change is far below the transition from oxide to sulfide ore and represents the primary metal zoning at Monte Negro. Other elements show different patterns. For example, barium concentrations do not change with depth, and zinc concentrations appear to increase downward (Russell et al. 1986; Kesler et al. 2003). More
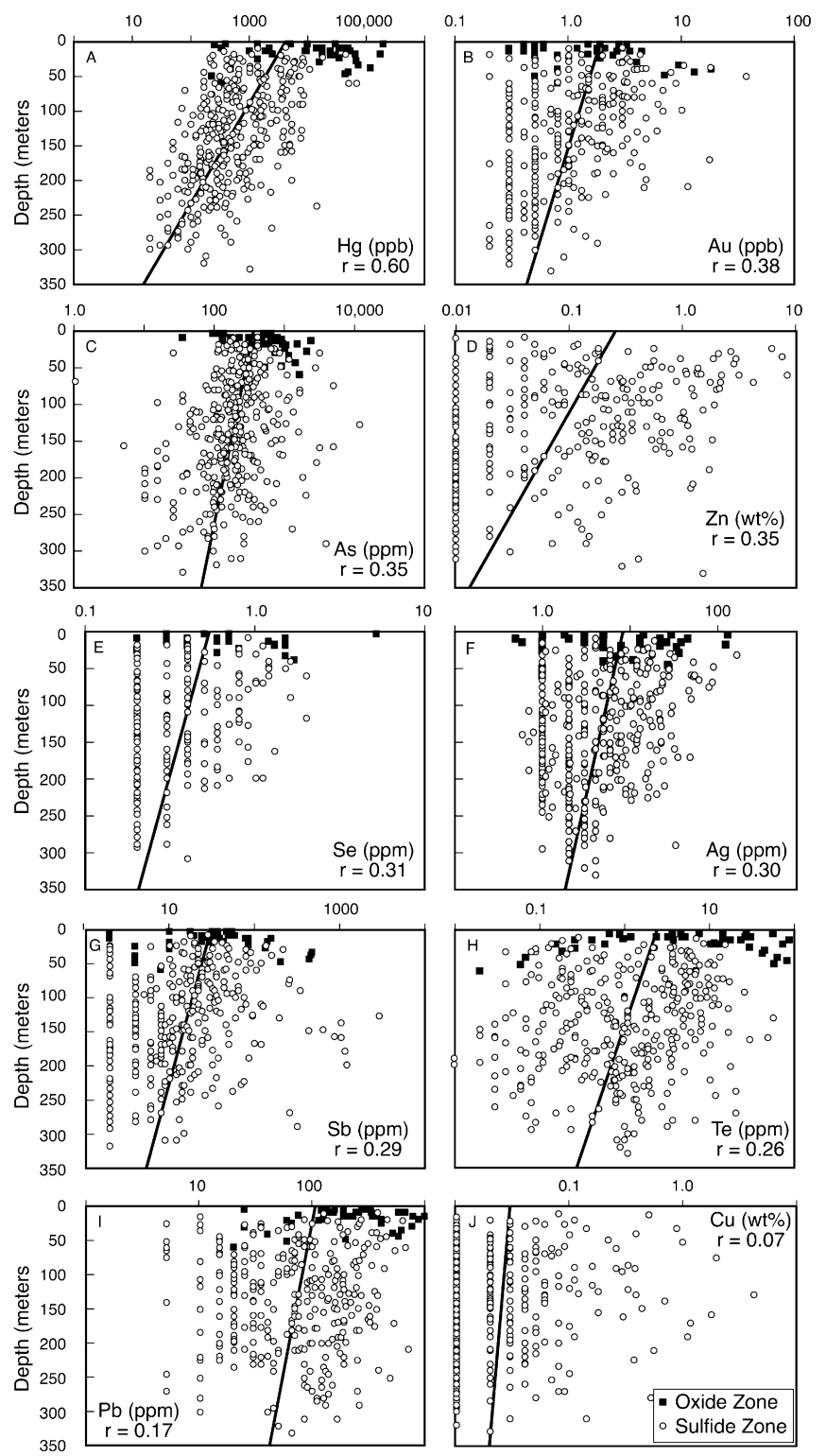

Fig. 7A-J Vertical zoning in the Moore deposit of A mercury, B gold, $\mathbf{C}$ arsenic, $\mathbf{D}$ zinc, $\mathbf{E}$ selenium, $\mathbf{F}$ silver, $\mathbf{G}$ antimony, $\mathbf{H}$ tellurium, I lead, and $\mathbf{J}$ copper, listed in order of decreasing correlation coefficient $(r)$ between grade and elevation

interestingly, concentrations of mercury and possibly tellurium at Monte Negro appear to increase steadily upward (Fig. 8). Although this enrichment is not as abrupt as that seen at Moore, it probably reflects the same process.

\section{Significance of the trace-element data to geochemistry of high-sulfidation deposits}

Form of vertical trace-element zoning

The different vertical zoning patterns seen at Moore and Monte Negro reflect differing degrees of erosional exposure of the two systems. The top of the Moore 

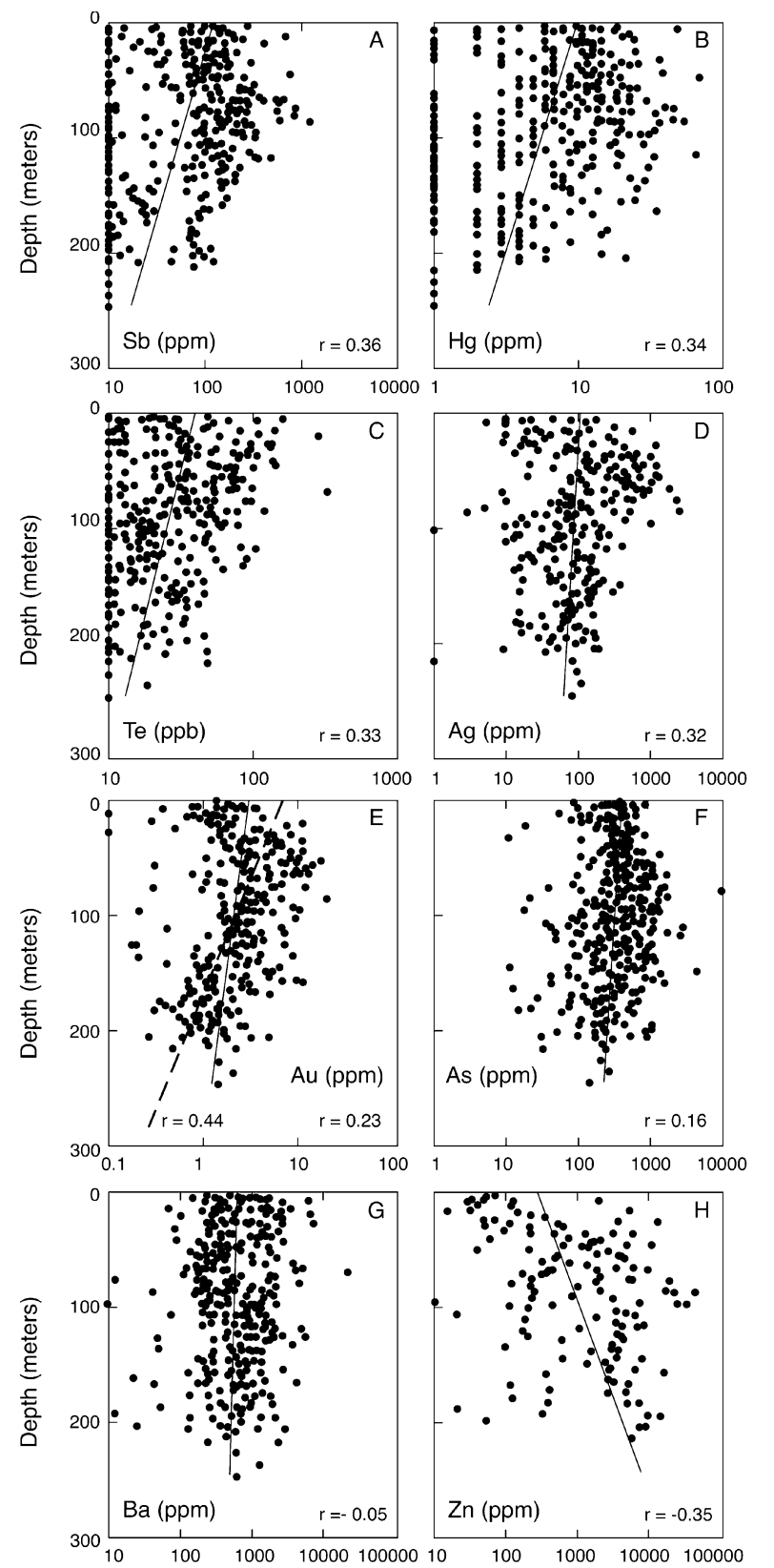

Fig. 8A-H Vertical zoning in the Monte Negro deposit of $\mathbf{A}$ antimony, $\mathbf{B}$ mercury, $\mathbf{C}$ tellurium, $\mathbf{D}$ silver, $\mathbf{E}$ gold, $\mathbf{F}$ arsenic, $\mathbf{G}$ barium, and $\mathbf{H}$ zinc, listed in order of decreasing correlation coefficient ( $\mathrm{r}$ ) between grade and elevation (with negative correlation for zinc listed last). Correlation coefficients were calculated for samples from all depths; as discussed in the text, correlations are better for samples below depths of 50 to $70 \mathrm{~m}$

deposit has been removed by erosion whereas the Monte Negro ore body is more nearly in its original form, although several hundred meters of overlying rock has probably been removed by erosion. Thus, the pattern of vertical zoning seen at Monte Negro, which involves steadily increasing concentrations upward into the ore zone, followed by decreasing concentrations above the ore zone, is probably typical of both deposits. The ore zone created by this zoning pattern is about $100-200 \mathrm{~m}$ thick, depending on cutoff grade, and is similar in its restricted vertical dimensions to ore shoots typical of many low-sulfidation epithermal deposits (Loucks and Petersen 1988; Cooke and Simmons 2000). The increase in grade upward through the lower part of ore zones probably resulted from a gradual decrease in the temperature and metal content of successive pulses of fluid flowing into the lower part of the system. The decrease in grade upward in the upper part of the ore zones could have resulted from decreasing metal concentrations in the cooling fluid and dilution by increased deposition of silica.

\section{Transport and deposition of the trace metals}

Element correlations and depth-abundance patterns described above provide some insights into the forms in that trace elements were dissolved in mineralizing solutions at Pueblo Viejo. Solubilities of most metals in hydrothermal solutions increase gradually with increasing temperature. Although specific solubilities will depend on the composition of the solution, most change by at least an order of magnitude over the 100 to $200{ }^{\circ} \mathrm{C}$ temperature range that probably prevailed upward through the Moore and Monte Negro deposits. For example, the solubility of gold in solutions buffered by sulfate and sulfide, and at the $\mathrm{pK}$ of $\mathrm{H}_{2} \mathrm{~S}$, decreases by slightly less than an order of magnitude between 250 and $100{ }^{\circ} \mathrm{C}$ (Seward 1973; Shenberger and Barnes 1989). Solubilities of galena and sphalerite as chloride complexes decrease by about two orders of magnitude between about 250 and $100{ }^{\circ} \mathrm{C}$, whereas solubilities as bisulfide complexes decrease much less (Giordano and Barnes 1979; Hayashi et al. 1990). The strong decrease in zinc abundance upward through the Pueblo Viejo system suggests that it was carried by chloride complexes. The much less distinct change upward in lead concentrations may mean that it was dominated by sulfide complexes, although very high reduced sulfide activities would be required to stabilize these complexes.

The enrichment of mercury in the uppermost part of the Moore and, to a lesser extent, Monte Negro deposits suggests that mercury was partitioned into a rising vapor phase by boiling, in agreement with experimental solubility data (Barnes and Seward 1997; Fein and WilliamsJones 1997). Cooke and McPhail (2001) have shown that tellurium is also partitioned strongly into the vapor phase during boiling of epithermal ore fluids, suggesting that the increase in tellurium values in the uppermost part of the deposits also reflects this process. Gold, silver and antimony can also be transported by a vapor phase under favorable conditions (Migdisov et al. 1999; Archibald et al. 2001; Zakaznova-Iakovleva et al. 2001). However, the vertical distribution of these elements provides no support for this process at Pueblo Viejo, probably because the fluids were not sufficiently hot.

Additional insights into metal complexing and deposition at Pueblo Viejo can be gained by comparison 
of our data to the results of Spycher and Reed (1989) who calculated the change in concentration of metals in a $280{ }^{\circ} \mathrm{C}$ solution typical of the Broadlands, New Zealand geothermal system, which cooled with boiling and no fractionation (i.e., removal) of minerals or gasses formed during the process. They showed that the mercury content of the hydrothermal fluid decreased by about three orders of magnitude, largely through loss to the vapor phase during boiling. Gold, silver, lead, zinc and copper contents decreased by about an order of magnitude, and arsenic and antimony contents remained about the same, indicating limited deposition of the latter two metals. The magnitude of upward solubility changes for mercury, gold, silver, and zinc in the Broadlands system is similar to that of the Moore and Monte Negro deposits, suggesting that solubility controls for these elements were similar in the two hydrothermal systems. The fact that arsenic- and antimonybearing minerals were deposited at Pueblo Viejo but not in the Broadlands calculation may be related to differences in complexing ligands. Arsenic and antimony were probably dissolved as $\mathrm{H}_{3} \mathrm{AsO}_{3}{ }^{0}$ and $\mathrm{H}_{3} \mathrm{SbO}_{3}{ }^{0}$, respectively, at Broadlands but may have formed polysulfide complexes at Pueblo Viejo, making them more likely to have been deposited by a boiling fluid (Williams-Jones and Normand 1997; Wood and Samson 1998; Cooke and Simmons 2000).

Possible mercury vapor haloes surrounding high-sulfidation epithermal deposits

Recognition that mercury and tellurium are concentrated in the upper parts of the Pueblo Viejo deposits by boiling suggests that these elements may serve as a guide to buried deposits of this type. Mercury mineralization is widespread above low-sulfidation epithermal deposits at Ivanhoe and Buckskin in Nevada, USA (Vikre 1985; Peppard 2002), and anomalous values of mercury in overlying rocks have been reported for high-sulfidation deposits at Yanacocha, Peru (Longo 2000). We were not able to test for mercury in overlying rocks at Pueblo Viejo because they have been removed by erosion, but we did carry out a reconnaissance survey of trace-metal abundances in altered rocks of the upper Los Ranchos Formation surrounding the deposit.

Advanced argillic and argillic alteration assemblages completely replace most rocks of the upper Los Ranchos Formation at the surface over an area of about 4 by $10 \mathrm{~km}$ surrounding and west of the Moore, Monte Negro and Cumba deposits (Fig. 9). Most of this altered rock is Platanal Member that forms an extensive dip slope along the southern side of the main hill in the area, known as Loma la Cuaba. Where a vertical section through these rocks is visible along the north side of Loma la Cuaba, rocks with advanced argillic assemblages appear to be about $50 \mathrm{~m}$ thick and to grade downward into spilite with mineral assemblages typical of seafloor metamorphism. Alteration may extend deeper

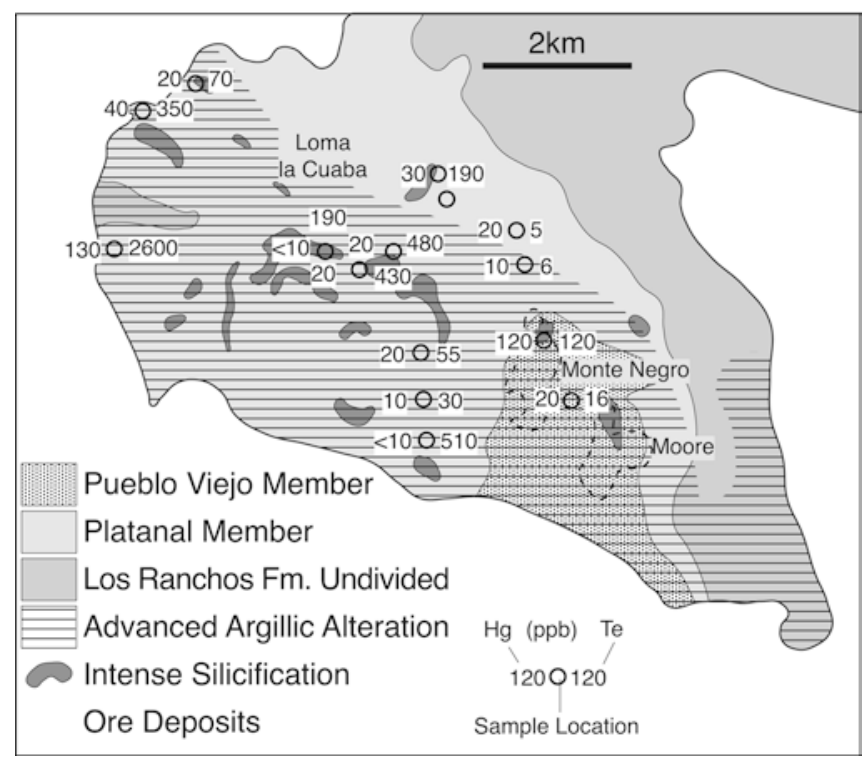

Fig. 9 Distribution of mercury and tellurium abundances in surface samples from altered rocks, including massive silicified zones, around the Pueblo Viejo district

beneath the central part of the Loma la Cuaba hill where large amounts of silicification are present at the surface. Pyrophyllite is the main alteration mineral found throughout this large volume of altered rocks, and it is bordered by illite and then merges into the regional calcite-chlorite alteration that formed during seafloor metamorphism (Bowin 1966; Wingfield 1973; Kesler et al. 1991). Some zones within this regional alteration are completely silicified and retain relict volcanic textures. They form stratiform masses that appear to be the westward continuation of the silicified zones overlying the Moore and Monte Negro deposits. Tellurium and mercury are the only trace elements in surface rock samples collected in this altered area that have significantly anomalous values. However, samples with highest values for these elements are not found near the known deposits. Instead, they are west of the ore deposits on Loma la Cuaba, where they may represent haloes above buried Pueblo Viejo-type mineralization.

Comparison to trace-metal abundances in other high-sulfidation epithermal systems

Trace-element zoning patterns comparable to those shown here for Pueblo Viejo have not been published, but limited data are available on average compositions of ores from a few other deposits. Average compositions can be compared by normalizing them to gold concentrations in the same sample or group of samples. It would be better to use an immobile element for this purpose, but data are not available for such elements. Because the extent of oxidation and supergene enrichment varies from deposit to deposit, comparisons are made here to average compositions, using both oxide 
and sulfide ore at the Moore deposit and comparing them to equivalent ore types in other deposits (Table 3).

Average compositions of the Akeshi, Kasuga and Iwato deposits in the Nansatsu district, Japan (Hedenquist et al. 1994) include all of the elements considered in this study. Although there is a relatively large difference in degree of oxidation of these deposits, with Kasuga being most oxidized and Akeshi least, there is relatively little difference in their element concentrations relative to gold. All deposits differ from Pueblo Viejo ore, however, in containing less arsenic, lead, zinc, and possibly less copper. At Paradise Peak, Nevada, USA, John et al. (1990) described a series of mineralizing events that began with early silica-sulfide alteration, followed by hydrothermal brecciation, early oxidation and leaching, black matrix hydrothermal brecciation, opal-jarosite matrix brecciation, and finally late oxidation and leaching. Compositional data for these ore types are similar to Pueblo Viejo sulfide ore, although black matrix ore is depleted in copper and tellurium relative to gold. At El Indio, Chile, Siddeley and Araneda (1986) recognized three main types of ore-massive enargitepyrite veins, late quartz-gold veins, and shallow baritealunite veins and breccias. Their estimated average composition of early enargite-pyrite veins is generally similar to that seen for sulfide ore at Pueblo Viejo (Fig. 10), except for mercury and silver that appear to be depleted (Fig. 10). These compositional differences may reflect different depths of formation for high-sulfidation deposits, with deposits such as Nansatsu and Paradise Peak, which formed at shallow depths, enriched in mercury and perhaps depleted in base metals and arsenic relative to probably deeper deposits such as El Indio and Pueblo Viejo.

\section{Conclusions}

Tellurium, not gold, is the most highly concentrated element relative to crustal averages in the Pueblo Viejo high-sulfidation epithermal deposits. In declining degree of concentration, tellurium is followed by gold, mercury, arsenic, antimony, and silver, all of that are concentrated by about 100 to 400 times above crustal average abundances. Copper, zinc, and selenium are concentrated to a much lesser degree, and barium does not appear to have been concentrated at all. Instead, barium released by alteration of enclosing wall rocks was deposited as barite by sulfate-bearing mineralizing solutions.

Element distribution patterns differ at the Moore deposit where the upper part of the ore body has been removed by erosion, and at the Monte Negro deposit where more of the upper part remains. At Moore, most elements increase continuously in concentration upward by about one to three orders of magnitude. At Monte Negro, element abundances show a similar upward increase to a maximum in the ore zone and then decrease more rapidly toward similar low levels. Mercury

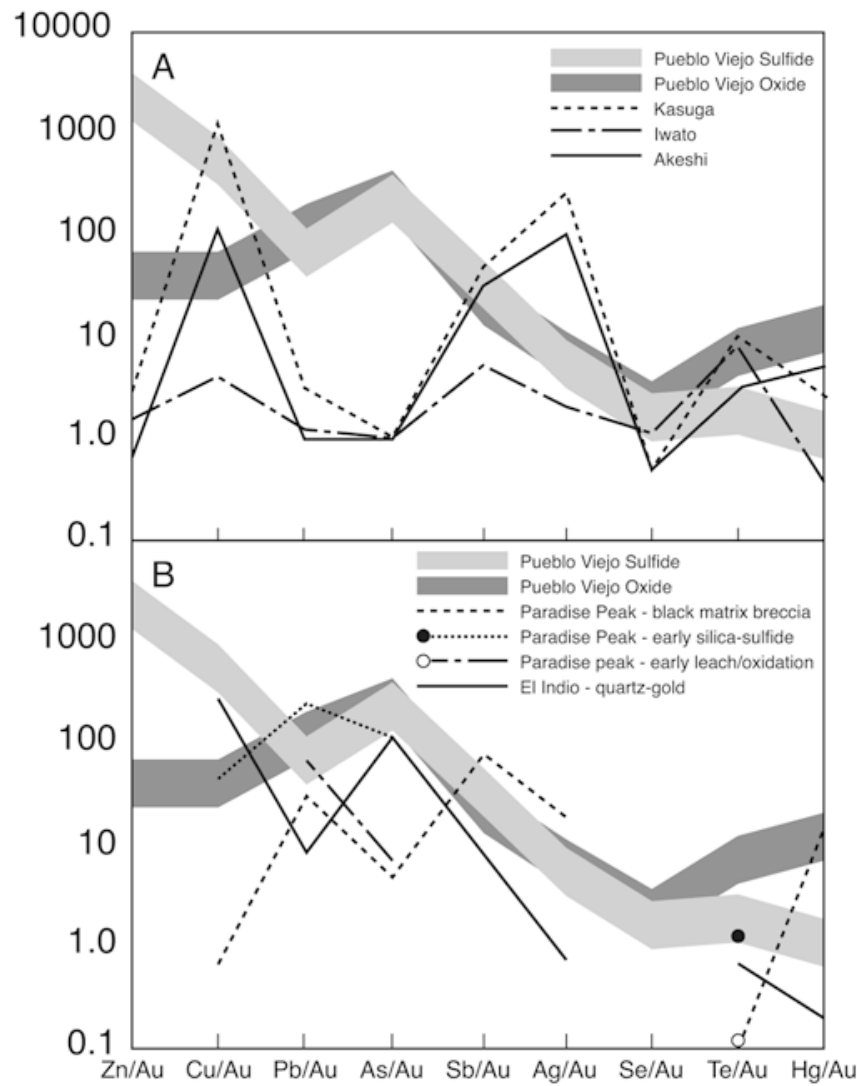

Fig. 10A, B Abundances of elements relative to gold in Pueblo Viejo sulfide and oxide ore compared to those in high-sulfidation deposits at Paradise Peak (Nevada), El Indio (Chile), and Nansatsu (Japan; Siddeley and Araneda 1986; John et al. 1990; Hedenquist et al. 1994)

abundances show an upward increase similar to that of other elements, but remain constant or decrease much more slowly upward above the ore zone, probably reflecting upward transfer of mercury from a boiling hydrothermal fluid. Tellurium abundances appear to show a similar, although less well-defined pattern. Barium abundances show little or no change upward and may be depleted in the ore zone. The resulting distribution of elements in and surrounding the Pueblo Viejo system is shown schematically in Fig. 11, where element zoning is divided into three main types typified by gold, mercury and barium.

The increase and then decrease upward of most element concentrations at Pueblo Viejo result in an ore zone that is similar in general form to the ore shoots typical of low-sulfidation epithermal deposits, except that it occupies a large volume of rock rather than a single vein (Cooke and Simmons 2000). Other highsulfidation epithermal deposits probably have trace-element zoning patterns of this type, but other deposits have not been characterized in the detail shown here. Despite our familiarity with Pueblo Viejo geology, we did not anticipate the zoning pattern that emerged for all elements from this study. Similar surprises may await others who characterize the trace-element geochemistry 
Fig. 11 Schematic illustration of distribution of trace elements, and their relation to ore and alteration zoning in and above the Pueblo Viejo highsulfidation deposits. The pattern for gold is typical of most other trace elements, especially arsenic, antimony, and silver. The pattern for mercury is probably typical also of tellurium. The pattern for barium is unique to that element and shows either no enrichment or a depletion

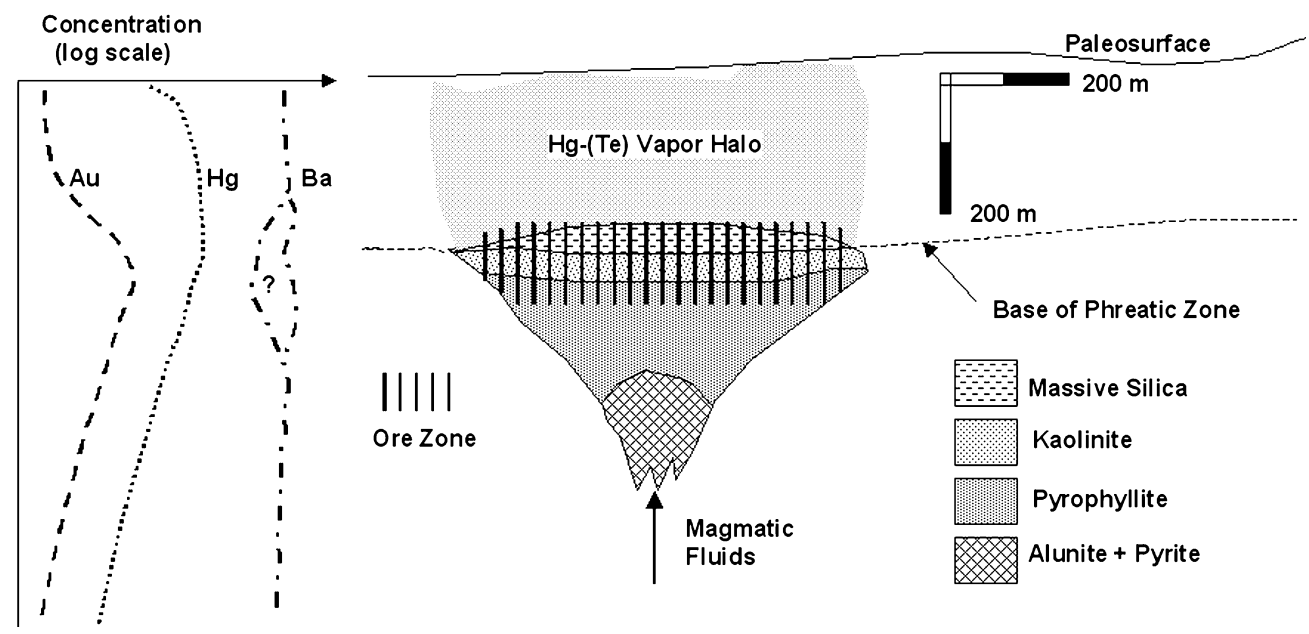

of their deposits in detail. Until such studies are more widely available, generalizations about trace-metal zoning in other deposits based on anecdotal information should be used with caution.

Acknowledgements We are grateful to Rosario Dominicana and particularly Michael Seaward, who was manager of the operation, for the opportunity to work at Pueblo Viejo and for funding this research. David Cooke, Jeff Hedenquist and Noel White provided insightful and helpful reviews of an earlier version of this manuscript.

\section{References}

Afifi AM, Kelly WC, Essene EJ (1988) Phase relations among tellurides, sulfides and oxides II. Applications to telluridebearing ore deposits: Econ Geol 83:395-404

Archibald SM, Migdisov AA, Williams-Jones AE (2001) The stability of Au-chloride complexes in water vapor at elevated temperatures and pressures. Geochim Cosmochim Acta 65:4413-4423

Barnes HL, Seward TM (1997) Geothermal systems and mercury deposits. In: Barnes HL (ed) Geochemistry of hydrothermal ore deposits, 3rd edn. Wiley, New York, pp 699-736

Bowin CO (1966) Geology of the Central Dominican Republic. Geol Soc Am Mem 98:11-84

Cooke DR, McPhail DC (2001) Epithermal Au-Ag-Te mineralization, Acupan, Baguio district, Philippines: numerical simulations of mineral deposition. Econ Geol 96:109-131

Cooke DR, Simmons SF (2000) Characteristics and genesis of epithermal gold deposits. In: Hagemann SG, Brown PE (eds) Gold in 2000. Rev Econ Geol 13:221-244

Fein JB, Williams-Jones AE (1997) The role of mercury-organic interactions in the hydrothermal transport of mercury. Econ Geol 92:20-28

Feiss PG (1974) Reconnaissance of the tetrahedrite-tennantite/ enargite-famatinite phase relations as a possible geothermometer. Econ Geol 69:383-390

Giordano TH, Barnes HL (1979) Ore solution chemistry VI. PbS solubility in bisulfide solutions to $300^{\circ} \mathrm{C}$. Econ Geol 74:16371646

Haas JL (1971) The effect of salinity on the maximum thermal gradient of a hydrothermal system at hydrostatic pressure. Econ Geol 66:940-946

Hayashi K, Sugaki A, Kitakaze A (1990) Solubility of sphalerite in aqueous sulfide solutions at temperatures between 25 and $240{ }^{\circ} \mathrm{C}$. Geochim Cosmochim Acta 54:715-725
Hedenquist JA, Matsuhisa Y, Izawa E, White HC, Giggenbach WF, Oaki M (1994) Geology, geochemistry, and origin of high sulfidation Au mineralization in the Nansatsu district, Japan. Econ Geol 89:1-30

Hemley JJ, Montoya JW, Marinenko JW, Luce RW (1980) Equilibria in the system $\mathrm{Al}_{2} \mathrm{O}_{3}-\mathrm{SiO}_{2}-\mathrm{H}_{2} \mathrm{O}$ and some general implications for alteration-mineralization processes: Econ Geol 75:210-228

Henley RW, Truesdell AH, Barton PB (1984) Fluid-mineral equilibria in hydrothermal systems. Rev Econ Geol 1

Hernandez PA, Garcia-Estrada PA, Cowley PN (1989) Geological setting, alteration and lithogeochemistry of the Transaccion epithermal gold deposit, Rodalquilar mining district, southeast Spain. Inst Mining Metall Trans Sect B 98:78-80

John DA, Nash JT, Clark CW, Wulftange WH (1990) Geology, hydrothermal alteration and mineralization at the Paradise Peak gold-silver-mercury deposit, Nye County, Nevada. In: Raines GL, Lisle RE, Schafer RW, Wilkinson WH (eds) Geology and ore deposits of the Great Basin. Geol Soc Nevada, Reno, pp 1020-1050

Kesler SE (1998) Geologic relations between Pueblo Viejo mineralization and the Los Ranchos Formation: the status in 1997. In: Feiss PG (ed) Mineral deposits of the Dominican Republic. SEG Fieldtrip Guideb, pp 31-36

Kesler SE, Russell N (2000) Discussion of: Nelson, C.E., Volcanic domes and gold mineralization in the Pueblo Viejo district, Dominican Republic. Miner Deposita 36:465-468

Kesler SE, Russell N, Seaward M, Rivera J, McCurdy K, Cumming GL, Sutter JF (1981) Geology and geochemistry of sulfide mineralization underlying the Pueblo Viejo gold-silver oxide deposit, Dominican Republic. Econ Geol 76:1096-1117

Kesler SE, Russell N, Polanco J, McCurdy K, Cumming GL (1991) Geology and geochemistry of the early Cretaceous Los Ranchos Formation, central Dominican Republic. In: Mann P Draper G, Lewis JF (eds) Geologic and tectonic development of the North America-Caribbean plate boundary in Hispaniola. Geol Soc Am Spec Pap 262:187-201

Kesler SE, Russell N, Sanchez R (2003) Abundancia y zonacion de metales y bario en el depósito, ácido-sulfato (alta sulfidación) Monte Negro, distrito de Pueblo Viejo, República Dominicana. Soc Geol Peru (in press)

Kettler RM, Rye RO, Kesler SE, Meyers PA, Polanco J, Russell N (1992) Gold deposition by sulfidation of ferrous $\mathrm{Fe}$ in the lacustrine sediments of the Pueblo Viejo district (Dominican Republic): the effect of Fe-C-S diagenesis on later hydrothermal mineralization in a maar-diatreme complex. Chem Geol 99:2950

Longo AA (2000) The San Jose-Careachugo-Chaquicocha gold trend, Yanacocha district, northern Peru. In: Cluer JK, Price PG, Struhsacker EM, Hardyman RF, Morris CL (eds) Geology 
and ore deposits 2000: the Great Basin and beyond. Geol Soc Nevada Symp Proc, 15-18 May 2000, pp 201-220

Loucks RR, Petersen U (1988) Polymetallic epithermal fissure vein mineralization, Topia, Durango, Mexico. Part II. Silver mineral chemistry and high resolution patterns of chemical zoning in veins. Econ Geol 83:1529-1559

Maske S, Skinner BJ (1971) Studies of the sulfosalts of copper. I. Phases and phase relations in the system $\mathrm{Cu}$-As-S. Econ Geol 66:901-918

McCurdy K, Russell N, Kesler SE (1986) Primary dispersion of trace elements and alteration zoning at the Pueblo Viejo $\mathrm{Au}-\mathrm{Ag}$ deposit, Dominican Republic. J Geochem Explor 25:259-260

Migdisov AA, Williams-Jones AE, Suleimenov OM (1999) Solubility of chlorargyrite $(\mathrm{AgCl})$ in water vapor at elevated temperatures and pressures. Geochim Cosmochim Acta 63:38173827

Muntean JL, Kesler SE, Russell N, Polanco J (1990) Evolution of the Monte Negro acid-sulfate Au-Ag deposit, Pueblo Viejo, Dominican Republic: important factors in grade development. Econ Geol 85:1738-1758

Nelson CE (2000) Volcanic domes and gold mineralization in the Pueblo Viejo district, Dominican Republic. Miner Deposita 35:1738-1758

Peppard B (2002) Geology and geochemistry of the Ivanhoe epithermal gold-silver deposit and its overlying silicified zones. MSc Thesis, University of Michigan, Ann Arbor

Posfai M, Buseck PR (1998) Relationships between microstructure and composition in enargite and luzonite. Am Mineral 83:373382

Russell N, Kesler SE (1991) Geology of the maar-diatreme complex hosting precious metal mineralization at Pueblo Viejo, Dominican Republic. Geol Soc Am Spec Pap 262:203-214

Russell N, Seaward M, Rivera JA, McCurdy K, Kesler SE, Cloke PL (1981) Geology and geochemistry of the Pueblo Viejo goldsilver oxide deposit, Dominican Republic. Trans Inst Mining Metall Sect B 90:25-34

Russell N, Polanco J, Kesler SE (1986) Geology of the Monte Negro gold-silver deposit, Pueblo Viejo district, Dominican Republic. In: Macdonald AJ (ed) Gold '86 Proc vol. Konsult International, Willowdale, ON, pp 497-503
Seward TM (1973) Thio complexes of gold in hydrothermal ore solutions. Geochim Cosmochim Acta 37:379-399

Shenberger DM, Barnes HL (1989) Solubility of gold in aqueous sulfide solutions from $150^{\circ}$ to $350^{\circ} \mathrm{C}$. Geochim Cosmochim Acta 53:269-278

Siddeley G, Araneda R (1986) The El Indio-El Tambo gold deposits, Chile. In: Macdonald AJ (ed) Gold '86 Proc vol. Konsult International, Willowdale, ON, pp 445-456

Sillitoe RH, Bonham HR Jr (1984) Volcanic landforms and ore deposits. Econ Geol 79:1286-1298

Simon G, Kesler SE, Essene EJ (1997) Phase relations among selenides, sulfides, tellurides and oxides. II. Applications to selenide-bearing ore deposits. Econ Geol 92:468-484

Spycher NF, Reed MH (1989) Evolution of a Broadlands-type epithermal ore fluid along alternative P-T paths: implications for the transport and deposition of base, precious, and volatile metals. Econ Geol 84:328-359

Turekian KK, Wedepohl KH (1961) Distribution of the elements in some major units of the Earth's crust. Geol Soc Am Bull $72: 175-192$

Vennemann TW, Muntean JL, Kesler SE, O’Neil JR (1993) Stable isotope evidence for magmatic fluids in the Pueblo Viejo epithermal acid-sulfate Au-Ag deposit, Dominican Republic. Econ Geol 88:55-71

Vikre PG (1985) Precious metal vein systems in the National District, Humboldt County, Nevada. Econ Geol Bull Soc Econ Geol 80:360-393

Williams-Jones AE, Normand C (1997) Controls of mineral paragenesis in the system Fe-Sb-O. Econ Geol 92:308-324

Wilson HDB (1944) Geochemical studies of the epithermal deposits at Goldfield, Nevada. Econ Geol 39:37-55

Wingfield R (1973) Pyrophyllite distribution and occurrence at the Pueblo Viejo gold mine. BSc Thesis, University of Toronto

Wood SA, Samson IA (1998) Solubility of ore minerals and complexation of ore metals in hydrothermal solutions. In: Richards JP, Larson PB (eds) Techniques in hydrothermal ore deposits geology. Soc Econ Geol Rev Econ Geol 10:33-80

Zakaznova-Iakovleva VP, Migdisov AA, Suleimenov OM, Williams-Jones AE, Alehjin YV (2001) An experimental study of stibnite solubility in gaseous hydrogen sulfide from 200 to $320^{\circ} \mathrm{C}$. Geochim Cosmochim Acta 65:289-298 